\title{
EXAMINATION OF THE RELATIONSHIP BETWEEN PERSONALITY TRAITS AND VOCATIONAL INTERESTS: IN A SAMPLE OF THE UK UNDERGRADUATE STUDENTS ${ }^{1}$
}

\author{
KISŞİLIKK ÖZELLIKLERİ VE MESLEKİ İLGİ ALANLARI ARASINDAKİ İLISŞKININ \\ İNCELENMESİ: BİRLEŞİK KRALLIK LİSANS ÖĞRENCILERİ ÖRNEĞİ
}

\author{
Ufuk BARMANPEK ${ }^{2}$ - Catherine STEELE ${ }^{3}$
}

\begin{abstract}
The main purpose of this study is to explore the relationship between personality traits ("dark" (as Dark Triad) and "bright" (as HEXACO)) and vocational interests (i.e. RIASEC) in individualist (UK) culture, achieved by considering Individualism-Collectivism (I-C) Theory within a group of undergraduate students in the UK. The participants were 445 individualist undergraduate students. The results indicated that apart from other relations, Extraversion (part of 'bright' side) and Dark Triad personality traits are positively, while Honesty-humility (part of 'bright' side) is negatively correlated with Enterprising, suggesting that these could be considered together when examining the relationship between personality and vocational interests. Limitations, implications and further studies are also discussed.
\end{abstract}

Keywords: HEXACO and Dark Triad Personality Traits, RIASEC Vocational Interests, Undergraduate Students, The UK.

$\ddot{O} \mathbf{z}$

Bu çalışmanın ana amacı, bireyci (BK) kültürde kişilik özellikleri ("karanlık” (yani Karanlık Üçlü) ve "aydınlık” (yani HEXACO)) ile mesleki ilgiler (yani RIASEC) arasındaki ilişkiyi Birleşik Krallık'taki bir grup lisans öğrencisi içinde Bireycilik-Kolektivizm (IC) Teorisini dikkate alarak araştırmaktır. Katılımcılar 445 bireyci kültürden gelen lisans öğrencilerinden oluşmaktadır. Sonuçlar gösteriyor ki, ilişkilerin yanı sıra Dışadönüklük ('aydınlık' tarafın bir parçası) ve Karanlık Üçlü kişilik özellikleri olumluyken, Dürüstlük-alçakgönüllülük ('aydınlık' tarafın bir parçası) Girişimcilik ile negatif korelasyon göstermekte ve kişilik ve mesleki ilgilerarasındaki ilişkiyi incelerken birlikte ele alınabilir. Sınırlamalar, çıkarımlar ve daha ileri çalışmalar ayrıca tartışılmaktadır.

Anahtar Kelimeler: HEXACO ve Dark Triad Kişilik Özellikleri, RIASEC Mesleki İgiler, Lisans Öğrencileri, Birleşik Krallık.

\footnotetext{
${ }^{1}$ This study was drived from a PhD Thesis written by Dr. Ufuk Barmanpek at Leicester University, UK.

${ }^{2}$ Ass. Prof., Faculty of Science and Literature, Psychology, ubarmanpek@bingol.edu.tr, Orcid: 0000-0003-14734841

${ }^{3}$ Dr., University of Leicester, Department of Neuroscience, Psychology and Behaviour, cs589@1e.ac.uk, Orcid: 0000-0003-4793-0726
}

Makale Türü: Araştırma Makalesi - Geliş Tarihi: 18.01.2021 - Kabul Tarihi: 24.05.2021

DOI:10.17755/esosder.862105

Atıf için: Elektronik Sosyal Bilimler Dergisi, 2021;20(80): 1997-2008

Etik Kurul İzni: University of Leicester. Ethic Reference: 9121-ub12-neuroscience,psychologyandbehaviour. 26.10.2016 


\section{Introduction}

Burr (1995) stated that cultural context is an important environmental factor which influences the relationship between personality traits and vocational interests. Based on this view, personality traits and vocational interests have been extensively investigated with regard to the cultural context in the vocational and occupational psychology literature (Fan et al., 2012). A result of this cultural examination is an overarching context of personality and vocational interests which can be easily interpreted in relation to cultural differences (Markus \& Kitayama, 1998). As evidence of this, some cultures provide an environment in which individuals can pursue their lives in a way which is purely directed by their personalities and interests. For instance, in individualist cultures, the examination of personality traits, vocational interests and their relationship can help individuals to shape their career and personal preferences. In contrast, other cultures might invoke family- and society-related expectations which might limit the role of personality and vocational interests (Ott-Holland et al., 2013). Due to these differences, culture, as an important factor in personality and vocational interests, is categorised into collectivism and individualism in order to define and explore individual differences more easily (Soh \& Leong, 2002).

Notably, a number of studies have emerged surrounding the concepts of individualism and collectivism which represent the specific features of individuals within their respective social groups (Hofstede, 1980). It has been noted that people in individualist cultures see themselves as autonomous agents and tend to be motivated by their own aims and preferences (Hofstede, 1980; Hsu, 1960), whereas people in collectivist cultures have relatively stronger relationships with their families, co-workers and social groups and tend to share similar cultural views and demands (Hui \& Triandis, 1986). Furthermore, in collectivist cultures, people tend to desire to belong to any social group in order to meet their own needs. With regard to cultures being considered in terms of their orientations, Schwartz (2006, p. 137) grouped countries into seven cultures; West European, English-speaking, Latin American, East European, South Asian, Confucian-influenced and African and Middle-Eastern. Based on this cultural categorisation, individualism is more prevalent in industrialised individualist countries (that is, in, West European, English-speaking and East European countries). In contrast, collectivism is more prevalent in developing and under-developed countries such as Latin American, African and Asian and Middle-Eastern countries (Oyserman et al., 2002).

\section{Individualism-Collectivism Theory}

The Individualist and Collectivist (I-C) theory developed from the work of Hofstede (1980) and his writings on cultural consequences. This theory has not been confined just to psychology but has also arisen in different fields of the social and humanitarian sciences. From the early 1970s, American psychologists and social scientists have been concerned with individualism in US society (Kagitcibasi, 1997). Because of this interest, the saliency of the IC concept has notably increased. Since the 1980s, a cross-cultural examination of this concept has arisen (Triandis, 1995) in cross-cultural psychology. Hofstede (1991, p. 51) described individualism as pertaining to "societies in which the ties between individuals are loose; everyone is expected to look after himself or herself and his or her immediate family", whilst collectivism "pertains to societies in which people from birth onwards are integrated into strong, cohesive in-groups, which throughout people's lifetime continue to protect them in exchange for unquestioning loyalty". Triandis (1994, p. 50), in the same vein, defined both collectivism and individualism as "cultural syndromes" which cause differences in cultures with regard to behaviours, values, beliefs and attitudes. Triandis also claimed that individualism and collectivism can be distinguished by four major attributes and individuals in collectivist cultures are described through their in-group relations, as seeking to achieve in- 
group connections, as obeying and corresponding to social norms and as behaving emotionally. Conversely, individuals in individualist cultures tend to act as more "autonomous atoms" and as having their own personal goals, as pursuing their desires and as behaving carefully in evaluating advantages and disadvantages (Sinha, 2014). To conclude, Dumont (1986) summarised that the differences between individualism and collectivism are not comprised only of societal differences but also of the differences among individuals.

\section{Existing Literature}

Personality and vocational interests exist differently in different cultures in terms of IC Theory. However, little is known about how these links manifest in individualistic cultures. Furthermore, it is important to identify whether the differences of those variables result in variations in relation to these specific relationships. This study thus investigates the relationship between personality traits and vocational interests in individualist UK undergraduate sample.

In regards to the relationships that arise between HEXACO-RIASEC, Realistic interests can be described as an "Adventure" characteristic that is negatively represented in those who score highly in Emotionality (Holtrop et al., 2015). Previous studies have provided mixed findings in regards to this relationship in different cultures. For example, individualist Dutch (Holtrop et al., 2015) and Canadian (Pozzebon et al., 2010) samples have provided similar findings, whereas a study with a collectivist African sample indicated no significant relationship between Neuroticism and Realistic (De Bruin, 2002).

The Investigative trait has the characteristic of being "cautious", with this being described in line with a Conscientiousness personality (McKay \& Tokar, 2012). Earlier studies have indicated that this relationship differs across cultures. For instance, Conscientiousness is positively related with Investigative interests in collectivist Taiwanese (Larson et al., 2007), and African (De Bruin, 2002) samples, while no such relation is found among an individualist Dutch sample (Holtrop et al., 2015).

Artistic interests, as include the characteristics of "creativity" and "imaginative", correspond to the characteristics of the Openness personality type (McKay \& Tokar, 2012). Previous studies have shown that this relation is consistent in both individualist and collectivist cultures - seen, for example, in Chinese (Wong \& Wong, 2006), Taiwanese (Larson et al., 2007; Wong \& Wong, 2006) Canadian (Pozzebon et al., 2010), Australian (Perera \& McIlveen, 2017), African (De Bruin, 2002) and American (Fan et al., 2012; McKay \& Tokar, 2012) samples.

Social interests have the characteristics of being "agreeable" and "considerate", as are the main factors in the Agreeableness personality type. The findings of earlier studies are also consistent in relation to both individualist and collectivist cultures - including in regards to collectivist cultures witnessed in China (Wong \& Wong, 2006) and Taiwan (Larson et al., 2007; Wong \& Wong, 2006), and the individualist cultures found in Canada (Pozzebon et al., 2010), Dutch (Holtrop et al., 2015), Australia (Perera \& Mcllveen, 2017) and America (McKay \& Tokar, 2012).

Enterprising refers to "acquisitive" and "exhibitionistic" characteristics, with this inversely corresponding to Honesty. Furthermore, the "assertiveness", "outgoing" and "sociable" characteristics of Enterprising are described in the same direction with the Extraversion personality type (McKay \& Tokar, 2012). A number of studies as to different cultures have provided similar findings in regards to these relations. In particular, Enterprising is negatively related with Honesty in the individualist cultures of America (McKay \& Tokar, 2012), Canada (Pozzebon et al., 2010) and Dutch (Holtrop et al., 2015), and is positively 
related with Extraversion in the collectivist cultures of China (Wong \& Wong, 2006), Taiwan (Larson et al., 2007) - with the individualist culture of Canada (Pozzebon et al., 2010) also witnessing this relationship.

Conventional interests involve task-oriented activities that are inversely related with Openness to Experience (Woods et al., 2013). In contrast to this assumption, some previous studies have failed to indicate any relationship between those variable in either the individualist cultures of Canada (Pozzebon et al., 2010) and America (McKay \& Tokar, 2012) or the collectivist culture of Taiwan (Larson et al., 2007).

In regards to the relationship between the Dark Triad Traits and RIASEC, Enterprising interests includes the characteristics of being "socially dominant" (Jonason \& Webster, 2012), "admired by others" (Jonason et al., 2014) and interested in demonstrating "power and prestige" (Babiak, 1995), with these also being dominantly represented in the Machiavellianism, Narcissism and Psychopathy traits respectively. In contrast to the HEXACO personality type, the relationship between the Dark Triad traits and RIASEC is much more limited, especially in collectivist cultures. Existing studies as to individualist cultures have shown that all Dark Triad traits are positively related with Enterprising (Schneider et al., 2017). In line with the discussions above, it has been found that Narcissism is positively related with Enterprising, while no relation is seen between Machiavellianism and Enterprising interests (Kowalski et al., 2017; McLarnon et al., 2015).

\section{Present Study}

This current study is significant in its replicating and supporting the existing literature by shedding more light in terms of understanding the relationships which arise between personality and vocational interests and by providing evidence from relatively individualist (the UK) culture. The I-C theory is a frequently applied model which operates by exploring individual differences across cultures (Hui \& Trandis, 1986). This is because the theory seeks to identify the similarities and differences which arise not only between but also within cultures (Peng et al., 1997). The existing studies related to the I-C theory are not sufficiently varied across cultures because, according to Kagitcibasi (1997), most I-C studies have been conducted in relation to individualist cultures (with the majority being US-based), and the studies have been conducted in collectivist cultures, including Japan and China (CaldwellHarris \& Aycicegi, 2006). Consequently, this current study focuses on examining UK sample because individuals in the UK are defined as highly individualist (Hofstede, 1980). This study can therefore contribute generally to the literature and the knowledge held about relations which arise between personality traits and vocational interests, while also contributing more specifically to the literature by taking into account the similarities and differences found across highly traditional individualist cultures. Additionally, this study can contribute to the relevant literature by shedding light on the nature of this relationship in a multi-cultural environment (such as UK).

\section{Method}

\section{Sampling and participants}

The current study has one sample. The sample consists of the participants from UK undergraduate students $(\mathrm{N}=445)$, with $16.4 \%$ male $(\mathrm{N}=73)$ and $83.6 \%$ female. The participants ranged from 17 to 31 years old with a mean age of 19.13 years old $(\mathrm{SD}=1.78)$. 


\section{Measures}

Mini-IPIP6 (Mini-International Personality Item Pool 6): This scale includes twenty-four items, twenty of that were developed by Goldberg in 1999 and integrated by Donnellan, Oswald, Baird and Lucas in 2006 within the distinctive Mini-IPIP Scale. The remaining four items, which represent Honesty Humility, were then added. The first two items, as adapted from the Narcissism Scale, were developed by Campbell, Bonacci, Shelton, Exline, and Bushman (2004). The last two items, as developed by Ashton and Lee (2009), were adapted from their HEXACO

Honesty-Humility Scale. The internal reliabilities of the scales were.72 for Honestyhumility, .60 for Emotionality,.75 for Extraversion, .71 for Agreeableness, .67 for Conscientiousness, and .70 for Openness for students. Exploratory (EFA) and Confirmatory factor analysis (CFA) can be used as evidence of construct validity (Campbell \& Fiske, 1959; Cronbach \& Meehl, 1955). Studies investigating the factor structure of Mini-IPIP confirmed a six-factor solution for the inventory for providing evidence of construct validity. Using EFA yielded a six underlying factor solution and CFA provided a best-fit model for the six-factor solution $\quad(\chi 2 \quad(237 ; \quad \mathrm{N}=2782)=3772.94, \quad \mathrm{p}<.01 ; \quad \mathrm{SRMR}=.057, \quad \mathrm{RMSEA}=.073, \quad$ Model CAIC $=4335.57$ ) (Sibley et al., 2012), suggesting that the scale was valid.

Short Dark Triad (3): This scale was once created by Paulhus and Jones (2011) to assess the Dark Triad variables. The scale has 3 subscales and includes twenty seven items on a five-point Likert-type scale starting from strongly Disagree (1) to strongly Agree (5). The internal reliabilities of Machiavellianism, Narcissism and Psychopathy were .79, .73, and .80 for the British students, respectively. The study examined the factor structure of the SDS (3) and the three-factor solution for the used scales for construct validity. The EFA findings provided a three-factor solution which was confirmed by CFA by providing the best-fit model, $\left(\chi 2=708.38, \mathrm{p}<0.01, \chi^{2} / \mathrm{df}=2.21\right.$, TLI=0.79, CFI=0.81, RMSEA=0.06) (Ozsoy et al., 2017).

The Interest Profiler Short Form: Rounds and colleagues created this scale in 1999 and it has six RIASEC dimensions; Realistic, Investigative, Artistic, Social, Enterprising and Conventional. Aside from long version scale, this short version includes sixty items. Every personality type has ten items and also the scales are rated on a five-point scale starting one (Strongly Dislike) to five (Strongly Like). This scale helps people to get their careers in terms of the styles of activity that are significantly associated to their interests (Rounds et al., 1999). The internal reliabilities of Realistic, Investigative, Artistic, Social, Enterprising and Conventional were $.88, .85, .86, .80, .87$, and .92 for students. The construct validity of this inventory was examined by EFA and subsequently CFA. The findings showed a six factors solution and the best-fit model $(\chi 2(300)=2,899.25, \mathrm{CFI}=.88, \mathrm{TLI}=.87, \mathrm{RMSEA}=.07)$ (Warlick et al., 2018). This short-form version of the scale was developed for application to counselling and consulting settings because it can be completed in a short time (Rounds et al., 1999).

\section{Procedures}

The relations among the variables were examined via sample of the UK undergraduates. Data was collected online via an EPR system (Experimental Participation Requirements) available for both students and researchers to collect and provide data. Students were informed as to the aim of the study in the consent form provided on the first page. Completing the survey took around 20 minutes. 


\section{Data Analysis}

The analyses were conducted using SPSS 24. First, the preliminary scores were calculated to ensure the data was appropriate for parametric tests. Following, the scores were calculated by Pearson product-moment correlation analysis to examine the relationship between personality traits and vocational interests.

\section{Results}

\section{Preliminary Analyses}

First, the assumptions of the parametric tests were tested. The findings showed that the parametric tests were appropriate regarding measurement level, dealing with outliers, normality, linearity and homoscedasticity for the data analysis. Additionally, the skewness and kurtosis criteria were met, ranging between $-/+1$ and therefore considered as 'very good' (Curran et al., 1996; George \& Mallery, 2010).

\section{Pearson product-moment Correlation Analysis}

This study examined the relationship between personality traits and vocational interests in the UK by performing Pearson product-moment correlation analysis was carried out.

Table 1 shows that a negative relationship was found between Honesty-Humility and Enterprising ( $\mathrm{r}=-.24)$. Openness was also found to be positively related with Artistic for $(\mathrm{r}=.37)$. Also, a negative relationship was found for the UK sample $(\mathrm{r}=-.16)$. The relationship between Extraversion with Enterprising $(\mathrm{r}=.22)$, and Social $(\mathrm{r}=.16)$, were found positively related. Additionally, no significant relation was found $(\mathrm{r}=.03)$. A negative relationship was found between Emotionality and Realistic ( $\mathrm{r}=-.16)$ and in regards to the relationship between Agreeableness and Social, a positive relationship was found for both samples ( $\mathrm{r}=.40)$.

Additionally, the Dark Triad traits and RIASEC relations were examined. Here, Machiavellianism was positively related with Enterprising $(\mathrm{r}=.10)$, and the relationship between Narcissism and Enterprising was positive $(r=.29)$. Finally, Psychopathy was positively related with Enterprising ( $\mathrm{r}=.10)$. 
Table 1: Personality traits and vocational interests correlations from the UK sample $(\mathrm{N}=445)$

\begin{tabular}{lcccccc}
\hline & Realistic & Investigative & Artistic & Social & Enterprising & Conventional \\
\hline Extraversion & $-.11^{*}$ & $.11^{*}$ & .03 & $.16^{* *}$ & $.22^{* *}$ & -.08 \\
Agreeableness & $-.15^{* *}$ & .06 & $.12^{* *}$ & $.40^{* *}$ & -.06 & $-.18^{* *}$ \\
Conscientiousness & -.00 & .03 & $-.13^{* *}$ & $.11^{*}$ & .07 & .03 \\
Emotionality & $-.16^{* *}$ & -.02 & -.01 & .09 & -.04 & -.07 \\
Openness & -.05 & .09 & $.37^{* *}$ & $.13^{* *}$ & -.08 & $-.16^{* *}$ \\
Honesty Humility & -.03 & .01 & -.01 & $.10^{*}$ & $-.24^{* *}$ & $-.11^{*}$ \\
Machiavellianism & .08 & .05 & .00 & $-.19^{* *}$ & $.10^{*}$ & $.10^{*}$ \\
Narcissism & .05 & .08 & .06 & -.05 & $.29^{* *}$ & .08 \\
Psychopathy & $.25^{* *}$ & .04 & .07 & $-.24^{* *}$ & $.10^{*}$ & $.23^{* *}$ \\
\hline
\end{tabular}

Note. ${ }^{* *}$. Correlation is significant at the 0.01 level (2-tailed)

*. Correlation is significant at the 0.05 level (2-tailed)

\section{Discussion}

This study has sought to examine whether the relationship between personality traits and vocational interests differs on the UK undergraduate students.

Specifically, we examined the relationship between Honesty-Humility and Enterprising, with the gained findings indicating that a negative relationship was found. As evidence of this, Honesty-Humility was negatively attributed to business and managing activities (as are described as Enterprising tendencies) (McKay \& Tokar, 2012; Pozzebon et al., 2010). Previous studies have observed individualist cultures in this relation (Holtrop et al., 2015; McKay \& Tokar, 2012; Pozzebon et al., 2010). Although no study has examined this specific relation in collectivist cultures, in the current study the results were in accordance and correspond to earlier studies. Also, it sought to examine the relationship between Openness and Artistic. The findings have shown that Openness was positively related with Artistic. This is in line with previous studies that have been conducted as to both collectivist and individualist cultures (De Bruin, 2002; Fan et al., 2012; Larson et al., 2007; McKay \& Tokar, 2012; Perera \& McIlveen, 2017; Pozzebon et al., 2010; Wong \& Wong, 2006; Zhang, 2008). Sagiv and Roccas (2000) have stated that Openness is manly endorsed in Western cultures as its characteristics of independence and open-mindedness tend to be seen in Western contexts. In contrast, individuals low in Openness are more likely to be more traditional and conservative, characteristics of collectivist cultures (Zhang, 2008). As evidence of this, the results of this study have shown that Openness was stronger. Moreover, Artistic activities are preferred in creative expression activities as individuals reflect their ideas through the performing of Artistic activities (Leuty et al., 2016). Although this study does not support such a conclusion, females are prone to prefer these Artistic activities and are expected to have a high score in relation to Artistic tendencies (Fouad, 2002). As the female UK participants strongly skew the sample, this might dominate the findings.

It was also sought to examine the relationship between Openness and Conventional, a negative relationship was found in the individualist culture. However, when previous studies 
are reviewed, the findings are in line with the understandings held as to collectivist cultures (Larson et al., 2007; McKay \& Tokar, 2012; Pozzebon et al., 2010).

Additionally, it was sought to examine the relationship between Extraversion and Enterprising across cultures, with the results have shown that a positive relationship was found in the UK sample. This is relatively meaningful as extraverted individuals tend to be involved in activities that require interaction with others. Additionally, previous studies have produced consistent findings here (Holtrop et al., 2015; Larson et al., 2007; Pozzebon et al., 2010; Wong \& Wong, 2006; Zhang, 2008).

It also was sought to examine the relationship between Conscientiousness and Investigative, no relationship was found in the individualist culture. In the individualist culture, similar findings were revealed (Holtrop et al., 2015; McKay \& Tokar, 2012) and similar findings were observed in relation to collectivist cultures (e.g. Larson et al., 2007).

Moreover, it was sought to examine the relationship between Emotionality and Realistic, whereby the results have indicated that a negative relationship was found. Previous research has also supported this point of view. For instance, according to Lee and Ashton (2008), individuals low in Emotionality are less likely to feel empathy and tend to be detached towards others. These characteristics could correspond to Realistic interests, as pertains to the "perceiving [of] self as lacking ability in human relations" characteristic (Holland, 1997, p.22). Thus, it is assumed that Emotionality is inversely related with Realistic. Other studies have supported the findings of the current study in terms of the individualist culture. In particular, Emotionality has been found to be negatively related within cultures (Holtrop et al., 2015; McKay \& Tokar, 2012; Pozzebon et al., 2007).

It was also sought to examine the relationship between Machiavellianism and Enterprising, with the results showing that a positive relationship was found. Observing these findings is meaningful as individuals high in Machiavellianism tend to be involved in activities pertaining to management and leadership (Kowalski et al., 2017). In this case, the participants from the individualist culture primarily consisted of females and it is assumed that Machiavellianism is expected to be lower among females. This may therefore have caused a significant difference as to this relation, despite Enterprising being found to be stronger in the individualist culture.

We sought to examine the relationship between Narcissism and Enterprising, with the results indicating that a positive relationship was found. This is relatively reasonable as individuals high in Narcissism tend to demonstrate exhibitionism, leadership, and dominance as correspond to Enterprising interests. A relative degree of support for this is seen in a number of recent studies (Kowalski et al., 2017; McLarnon et al., 2015; Schneider et al., 2017).

Lastly, we sought to examine the relationship between Psychopathy and Enterprising, with it being found that Psychopathy was positively related with Enterprising. This finding is also meaningful as individuals high in Psychopathic tendencies are more interested in business activities (including sales, management and executing actions) - areas known to be the major features of Enterprising. Only a few studies have examined this relationship, with focus mainly having been given to individualist cultures and the results gained have been somewhat mixed. Kowalkski et al. (2017) found similar results to the current study. In contrast, another study failed to find any significant relationship (McLarnon et al., 2015). 


\section{Limitations and Further Studies}

This study has several limitations and has also invoked several suggestions for further research. The first limitation is that the participants have been drawn from a minor group of students. In particular, there are two main limitations in terms of the participants. Firstly, the student participants filled in the survey via the EPR system, as is essentially solely used in the Psychology Department of Leicester University. Secondly, most of the participants were female and the gender effect may play a role in relation to the findings. Another limitation is that the current study has investigated only one culture; the UK. In this case, two conditions could be considered. First, university students may not be representative of the whole society of each respective nation. Secondly, solely using the UK sample may not be adequate for undertaking interpretations as to a general comparison. Therefore, further investigation should pertain to several countries, as will provide an extensive cross-cultural understanding. To minimise these limitations, future research should provide more heterogeneous and equallysized sample groups if more comprehensive and general results are to be gained.

\section{Implications}

Although existing studies have shown the effect of the relationship between personality traits and vocational interests in career exploration and organisational decisions, we do not have a clear understanding as to how this relationship is implemented in career decisions and recruitment strategies within the Turkish context. For instance, the findings of these studies can guide people towards making more appropriate career decisions (Woods et al., 2016). More specifically, career counsellors and practitioners will guide people towards more appropriate careers when considering the research findings here as to the relationship between personality traits and vocational interests. Additionally, people will be aware of their vocational preferences and how these preferences fit their personality in advance. Matching one's personality and vocational interests will enhance the possession of a high level of satisfaction and would thus make that person more employable. One of the important assessments of the recruitment process is the analysis as to the relationship match between person and environment (Kristof, 1996) through a consideration of the relationship between personality traits and vocational interests. This helps decision-makers to hold a general idea as to the personality and interests of the UK population and how this relationship arises. If people are guided into the right career in regards to their absolute personalities and vocational interests, they might be seen as more employable. From this, such individuals may be able to encounter better career opportunities and occupations that fit their personalities more closely.

\section{Conclusion}

In sum, this study has highlighted the relationship between personality traits and vocational interests in the UK culture by examining both bright and dark side of personality traits with RIASEC vocational interests. It can thus be suggested that the relationship between personality traits and vocational interests have some differences when investigated in different culture. In general, low on Honesty-Humility, high on Extraversion and Dark Triad personality traits were found consistently related with Enterprising. To sum, these results suggest that the relationship between personality and vocational interests in the UK across other cultures might differ in certain cases. However, this relationship does not differ in general. 


\section{References}

Babiak, P. (1995). When psychopaths go to work: A case study of an industrial psychopath. Applied Psychology, 44(2), 171-188.

Burr, V. (1995). An introduction to social constructionism. London, England: Routledge.

De Bruin, G.P. (2002). The relationship between personality traits and vocational interests. Journal of Industrial Psychology, 28(1), 49-52.

Caldwell-Harris, C.L., \& Aycicegi, A. (2006). When personality and culture clash: The psychological distress of allocentrics in an individualist culture and idiocentrics in a collectivist culture. Transcultural Psychiatry, 43, 331-361.

Campbell, D. T., \& Fiske, D. W. (1959). Convergent and discriminant validation by the multitrait-multimethod matrix. Psychological Bulletin, 56(2), 81-105.

Cronbach, L. J., \& Meehl, P. E. (1955). Construct validity in psychological tests. Psychological Bulletin, 52, 281-302.

Curran, P. J., West, S. G., \& Finch, J. F. (1996). The robustness of test statistics to nonmorality and specification error in confirmatory factor analysis.

Psychological Methods, 1(1), 16-29.

Donnellan, M. B., Oswald, F. L., Baird, B. M., \& Lucas, R. E. (2006). The Mini-IPIP Scales: Tiny-yet-effective measures of the Big Five Factors of Personality. Psychological Assessment, 18(2), 192-203.

Dumont, L. (1986). Essays on individualism. Chicago: University of Chicago Press.

Fan, W., Cheung, F. M., Leong, F. L., \& Cheung, S. F. (2012). Personality traits, vocational interests, and career exploration: A cross-cultural comparison between American and Hong Kong students. Journal of Career Assessment, 20, 105-119.

George, D., \& Mallery, P. (2010). SPSS for windows step by step: A simple guide and reference 17.0 update (10th ed.). Baston: Pearson.

Goldberg, L. R. (1990). An Alternative "Description of Personality": The Big-Five Factor Structure. Journal of Personality and Social Psychology, 59, 1216-1229.

Hofstede, G. (1980). Culture's consequences: International differences in work-related values. Beverly Hills, CA: Sage.

Hofstede, G. (1991). Cultures and Organizations: Software of the Mind. London, UK: McGraw-Hill.

Holtrop, D., Born, M. P., \& De Vries, R. E. (2015). Relating the Spherical representation of vocational interests to the HEXACO personality model. Journal of Vocational Behavior, 89, 10-20.

Hsu, F. L. K. (1960). Rugged individualism reconsidered. Colorado Review, 9, 143-62.

Hui, C. H., \& Triandis, H. C. (1986). Individualism-collectivism: A study of cross-cultural researchers. Journal of Cross-cultural Psychology, 17, 225-248.

Jonason, P.K., \& Webster, G.D. (2012). A protean approach to social influence: Dark Triad Personalities and Social Influence Tactics. Personality and Individual Differences, 52, 521-526. 
Jonason, P. K., Wee, S., Li, N. P., \& Jackson, C. (2014). Occupational niches and the Dark Triad traits. Personality and Individual Differences, 69, 119-123.

Kagitçibasi, C. (1997). Individualism and collectivism. In J. W. Berry, M. H. Segall, \& C. Kagitçibasi (Eds.), Handbook of cross-cultural psychology: Social behavior and applications (Vol. 3, pp. 1-49). Boston: Allyn \& Bacon.

Kowalski, C. M., Vernon, P. A., \& Schermer, J. A. (2017). Vocational interests and dark personality: Are there dark career choices? Personality and Individual Differences, 104, 43-47.

Larson, L. A., Wei, M., Wu, T.-F., Borgen, F. H., \& Bailey, D. C. (2007). Discriminating among educational majors and career aspirations in Taiwanese undergraduates: The contribution personality and self-efficacy. Journal of Counseling Psychology, 54, 395408 .

Leuty, M. E., Hansen, J. I. C., \& Speaks, S. Z. (2016). Vocational and Leisure Interests: A Profile-Level Approach to Examining Interests. Journal of Career Assessment, 24(2), 215-239.

Markus, H. R., \& Kitayama, S. (1991). Culture and the self: Implications for cognition, emotion, and motivation. Psychological review, 98(2), 224-253.

McKay, D. A. \& Tokar, D.M. (2012). The HEXACO and five-factor models of personality in relation to RIASEC vocational interests. Journal of Vocational Behavior, 81(2), 138149.

McLarnon, M. J. W., Carswell, J. J., \& Schneider, T. J. 2015. A case of mistaken identity? Latent profiles in vocational interests. Journal of Career Assessment, 23, 166-185.

Oyserman, D., Coon, H. M., \& Kemmelmier, M. (2002). Rethinking individualism and collectivism: Evaluation of theoretical assumptions and meta-analyses. Psychological Bulletin, 128, 3-72.

Ott-Holland, C., Huang, J. L., Ryan, A. M., Elizondo, F., \& Wadlington, P. L. (2013). Culture and vocational interests: The moderating role of collectivism and gender egalitarianism. Journal of Counseling Psychology, 60(4), 569-581.

Paulhus, D. L., \& Jones, D. N. (2011). Introducing a short measure of the Dark Triad. Poster presented at the meeting of the Society for Personality and Social Psychology, San Antonio.

Peng, K., Nisbett, R. E., \& Wong, N. Y. C. (1997). Validity problems comparing values across cultures and possible solutions. Psychological Methods, 2(4), 329-344.

Perera, H. N., \& McIlveen, P. (2017). Profiles of career adaptivity and their relations with adaptability, adapting, and adaptation. Journal of Vocational Behavior, 98, 70-84.

Pozzebon, J. A., Visser, B. A., Ashton, M. C., Lee, K., \& Goldberg, L. R. (2010). Psychometric characteristics of a public-domain self-report measure of vocational interests: The oregon vocational interest scales. Journal of Personality Assessment, 92(2), 168-174.

Rounds, J., Mazzeo, S.E., Smith, T.J., Hubert, L., Lewis, P., \& Rivkin, D. (1999). O*NET Computerized Interest Profiler: Reliability, validity, and comparability. Retrieved June 25, 2015, http://www.onetcenter.org/dl_files/IP_RVS.pdf. 
Sagiv, L., \& Roccas, S. (2000). Traits and values: The five-factor model and the Schwartz value theory. Paper presented at the 27th International Congress of Psychology, Stockholm, Sweden.

Schneider, T. J., McLarnon, M. J. W. \& Carswell, J. J. (2017). Career Interests, Personality, and the Dark Triad. Journal of Career Assessment, 25(2), 338-351.

Schwartz, S.H. (2006). 'A theory of cultural value orientations: explication and applications'. Comparative Sociology, 5(2), 137-182.

Sibley, C. G., Luyten, N., Purnomo, M., Mobberley, A., Wootton, L. W., Hammond, M. D., \& McLellan, L. (2011). The Mini-IPIP6: Validation and extension of a short measure of the Big-Six factors of personality in New Zealand. New Zealand Journal of Psychology, 40(3), 142-159.

Sinha J.B.P. (2014). Collectivism and Individualism. In: Psycho-Social Analysis of the Indian Mindset. Springer, New Delhi.

Soh, S., \& Leong, F. T. L. (2000). Cross-cultural validity of vertical and horizontal individualism and collectivism in Singapore: Relationships with values, interests, college majors and organizational preferences. Manuscript submitted for publication.

Triandis, H. C. (1994). Theoretical and methodological approaches to the study of collectivism individualism. In U. Kim, H. C. Triandis, C. Kagitcibasi, S. C. Choi, \& G. Yoon (Eds.), Individualism and collectivism: Theory, method, and application (pp. 4151). Thousand Oaks: Sage.

Triandis, H. C. (1995). Individualism and collectivism. Boulder, CO: West View Press.

Warlick, C. A., Ingram, P. B., Ternes, M. S., \& Krieshok, T. S. (2018). An Investigation into the Structural Form of the O*NET-Interest Profiler-Short Form. Journal of Career Assessment, 26(3), 503-514.

Wong, C. S., \& Wong, P. M. (2006). Validation of the Wong's career interest assessment questionnaire and the revised Holland's hexagonal model of occupational interests in four Chinese societies. Journal of Career Development, 32, 378-393.

Woods, S. A., \& Hampson, S. E. (2010). Predicting Adult Occupational Environments from Gender and Childhood Personality Traits. Journal of Applied Psychology, 95(6), 1045-1057.

Woods, S.A., Lievens, F., De Fruyt, F. \& Wille, B. (2013). Personality across Working Life: The Longitudinal and Reciprocal Influences of Personality on Work. Journal of Organizational Behaviour, 34, 7-25.

Zhang, L. F. (2008). Revisiting the big six and the big five among Hong Kong university students. Educational Psychology, 28, 1-14. 